\title{
Short-term and seasonal dynamics of bacterial biomass production and amino acid turnover in the water column of an intertidal ecosystem, the Wadden Sea
}

\author{
Andreas Lemke ${ }^{1}$, Mirko Lunau ${ }^{1,2}$, Thomas H. Badewien ${ }^{1}$, Meinhard Simon ${ }^{1, *}$ \\ ${ }^{1}$ Institute for Chemistry and Biology of the Marine Environment, University of Oldenburg, \\ PO Box 2503, 26111 Oldenburg, Germany
}

${ }^{2}$ Present address: Alfred Wegener Institute for Polar and Marine Research, 27515 Bremerhaven, Germany

\begin{abstract}
Intertidal flat systems exhibit systematic temporal patterns of suspended particulate matter (SPM) and associated properties (particulate organic carbon, chlorophyll) with enhanced concentrations towards the current velocity maximum (CVM) and reduced concentrations towards slack water. It is unclear how these tidal patterns are reflected in organic matter processing by particleassociated (PA) and free-living (FL) heterotrophic bacteria. Therefore, we studied the abundance of PA and FL bacteria, bacterial biomass production (BP) and turnover of dissolved free amino acids (DFAA) during tidal cycles in a 13 to $16 \mathrm{~m}$ deep back-barrier intertidal flat system of the East Frisian Wadden Sea, Germany, in January, April, July and November 2005. Pronounced tidal patterns of microbial parameters were found with distinct differences around the CVM and at slack water. Tidal patterns varied seasonally with higher BP rates and bacterial generation times of 1 to $2 \mathrm{~d}$ in April and July. There was a trend of enhanced rates of BP from surface to bottom in April and July with an increasing significance of PA bacteria towards the bottom. Very high depth-integrated daily rates of $\mathrm{BP}$ and oxygen undersaturation suggest that this system is net-heterotrophic. A normalization procedure revealed systematic tidal patterns of most parameters irrespective of the seasonal situation. Our findings thus demonstrate the presence of tidal patterns of parameters reflecting microbial processes and thus complement previous findings of tidal patterns of SPM-associated properties. The tidally varying microbial activities indicate that the rhythmic tidal currents promote organic matter decomposition by heterotrophic bacteria in intertidal flat systems.
\end{abstract}

KEY WORDS: Wadden Sea $\cdot$ Tidal dynamics $\cdot$ Free-living bacteria $\cdot$ Attached bacteria $\cdot$ Bacterial production · Amino acids

\section{INTRODUCTION}

Intertidal mud and sand flat ecosystems at the transition zone between land and coastal seas are strongly affected by inputs of inorganic nutrients and organic matter both from terrestrial as well as marine origin. These inputs result in high productivity and turnover of organic matter, making these intertidal areas one of the most productive marine ecosystems (Alongi 1998). Phytoplankton primary production is strongly light-limited and benthic primary production contributes up to $50 \%$ of total primary production (Soetaert \& Herman 1995, Underwood \& Kromkamp 1999, Tillmann et al. 2000, Wolfstein et al. 2000). Because of the additional allochthonous input of organic matter, intertidal mud and sand flat ecosystems are usually net-heterotrophic and act as a sink for organic matter (Cadée 1980, Postma 1981). They are, together with estuaries and mangrove ecosystems in the tropics and subtropics, of prime 
importance in organic matter processing in the coastal zone (Alongi 1998).

Tidal currents cause intense sedimentation and resuspension of particulates, resulting in permanently turbid water masses with high loads of suspended particulate matter (SPM). The SPM is dominated largely by inorganic constituents, despite the high input of organic matter, and is composed mostly of microaggregates $<500 \mu \mathrm{m}$, which undergo pronounced changes and restructuring during current velocity changes (Eisma \& Li 1993, Chen et al. 1994, Lunau et al. 2006, Bartholomä et al. 2009). In a back-barrier intertidal flat system of the German Wadden Sea, Lunau et al. (2006) identified regular tidal patterns of SPM and microaggregate abundance, particulate organic carbon (POC) and chlorophyll a (chl a) with distinct maxima shortly after the current velocity maximum (CVM) and minima at slack water. In contrast, free-living bacteria and concentrations of dissolved organic carbon (DOC) exhibited maxima around low tide and minima at high tide. Strong vertical gradients of SPM and chl a often exist in such systems with enhanced concentrations in the near-bottom layer (Poremba et al. 1999, Bartholomä et al. 2009).

Heterotrophic microbial processes are of prime importance in intertidal flat ecosystems. However, the role of heterotrophic bacteria in the turnover of organic matter in these systems and how tidal dynamics affect their growth and substrate turnover has been studied surprisingly little. Admiraal et al. (1985) and van Duyl \& Kop (1988) assessed seasonal dynamics of bacterioplankton biomass production in the Ems-Dollard estuary and the western part of the Dutch Wadden Sea, respectively, but only at high tide. Poremba et al. (1999) investigated tidal patterns of bacterial abundance and biomass production in the North Frisian Wadden Sea and found some covariations with tidal currents and SPM concentrations along with differences in the surface and bottom layer. Grossart et al. (2004) assessed bacterial growth and substrate dynamics over a tidal cycle in the German Wadden Sea but did not find systematic patterns. Except for the study by Poremba et al. (1999), the other studies are based on surface samples and do not take into account that the dynamic resuspension and the light conditions lead to an uneven distribution of SPM and the phytoplankton (chl a) in the water column of the tidal channels. Because of the regular tidal patterns of SPM, microaggregates and chl $a$ in intertidal flat systems (Lunau et al. 2006), we hypothesize that such patterns are also present for the abundance, growth, biomass production and substrate turnover of free-living (FL) and particle-associated (PA) bacterial communities.

The aim of this study was to investigate the abundance and biomass production of heterotrophic FL and
PA bacteria and the turnover of dissolved free amino acids (DFAA) during tidal cycles in spring, summer, fall and winter in an intertidal ecosystem, the German Wadden Sea. We focused on identifying tidal and vertical patterns of these parameters in the water column of this shallow ecosystem. The Wadden Sea, the coastal region of the North Sea between Den Helder (Netherlands) and Skallingen (Denmark), is the world's largest intertidal flat ecosystem and of general importance for land-sea interactions of the North Sea. In 2009 it was designated a UNESCO-world natural heritage site. The intertidal flat system of the back-barrier area of Spiekeroog Island in the East Frisian Wadden Sea has been the focus of intense studies of hydrographic and biogeochemical processes during the recent past (e.g. Grossart et al. 2004, Lunau et al. 2006, Dellwig et al. 2007, Bartholomä et al. 2009, Reuter et al. 2009, Rullkötter 2009, Stanev et al. 2009), which made this system well-suited for the present study.

\section{MATERIALS AND METHODS}

Study site and sampling. The study was carried out in 2005 at the inlet of the main tidal channel of the intertidal flat back-barrier system of Spiekeroog Island in the East Frisian Wadden Sea (Otzumer Balje, Stn OB9; $53^{\circ} 44.9^{\prime} \mathrm{N}, 07^{\circ} 40.0^{\prime}$ E; Fig. 1). Samples were collected during tidal cycles between 11 and 12 January, 26 and 27 April, 19 and 20 July, and 16 and 17 November from the surface, mid-depth (6 to $7 \mathrm{~m}$ ) and $1 \mathrm{~m}$ above the channel bed aboard RV 'Senckenberg'. A total of 7 samples were taken between 2 slack water situations, thus subdividing this period into 6 equal time slots. The water depth varied from 13 to $16 \mathrm{~m}$, depending on the season and tide. The mean tidal range was $2.6 \mathrm{~m}$. The studies were conducted at (January) and $1 \mathrm{~d}$ before (April) spring tide, $3 \mathrm{~d}$ after neap tide (July) and $3 \mathrm{~d}$ after spring tide (November), as reflected by the days to new moon (Table 1).

Samples were collected by bucket at the surface and by 2.51 Niskin bottles mounted on a rosette sampler at mid-depth and $1 \mathrm{~m}$ above the channel bed. Temperature, salinity and oxygen were determined by a SeaBird SBE 19plus CTD equipped with an SBE 43 oxygen sensor. Subsamples for all analyses were immediately withdrawn and further processed as described below. Sampling always started and ended at high tide. The exact sampling time was derived from a hydrographic model for the German Bight and the adjacent Wadden Sea (Bundesamt für Seeschiffahrt und Hydrographie, Hamburg, Germany) and water-level recordings from a time-series station located directly at Stn OB9 (Reuter et al. 2009, http://las.physik.uni-oldenburg.de/ wattstation/). At this station, meteorological, hydro- 


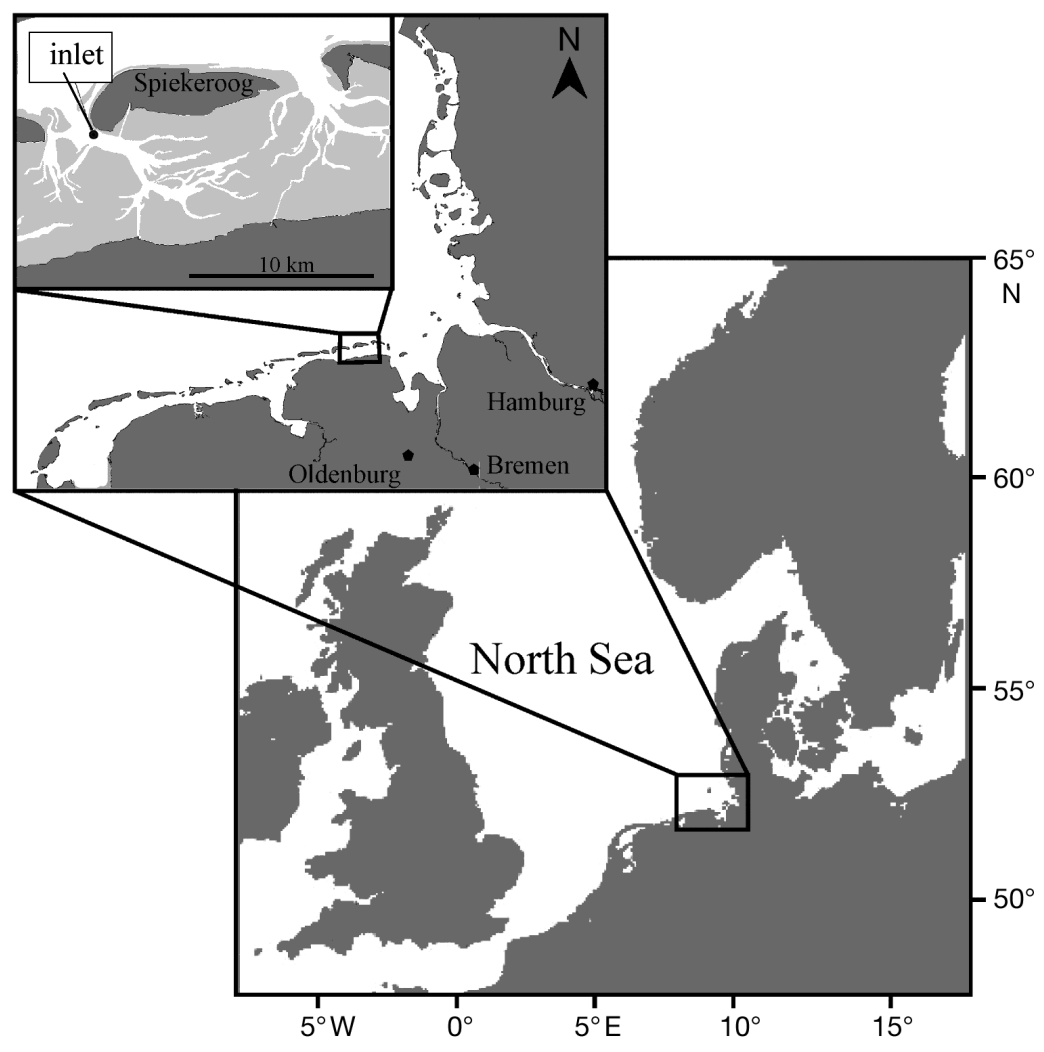
of Spiekeroog Island, German Wadden Sea
Fig. 1. Study area with the study site (inlet) in the back-barrier tidal flat system

frozen at $-20^{\circ} \mathrm{C}$ until further analysis in the shaded laboratory within $2 \mathrm{wk}$. Filters were mechanically chopped and extracted in hot ethanol $\left(75^{\circ} \mathrm{C}\right)$ for $1 \mathrm{~h}$ in the dark. Concentrations of chl a and phaeopigments were determined spectrophotometrically and calculated according to Nusch (1999).

Dissolved free amino acids. Concentration of DFAA was analyzed by high performance liquid chromatography (HPLC) after ortho-phthaldialdehyde precolumn derivatization as described in Lunau et al. (2006). Subsamples for DFAA analysis were filtered on shipboard by hand as gently as possible with $5 \mathrm{ml}$ glass syringes, pre-rinsed with ultra-clean water, through $0.2 \mu \mathrm{m}$ low protein binding filters (Tuffrin Acrodisc, Whatman) and kept frozen at $-20^{\circ} \mathrm{C}$ until analysis.

Bacterial cell numbers. Numbers of FL and PA bacteria were determined in glutardialdehyde-fixed ( $2 \%$ final concentration) samples, stored at $-80^{\circ} \mathrm{C}$ until analysis, by epifluorescence microscopy after SYBR Green I (Invitrogen) staining as described in detail by Lunau et al. (2005). Briefly, for enumeration of FL bacteria, subsamples were graphic (salinity, temperature, current velocity and direction) and inorganic nutrient (phosphate, nitrate, silicate and dissolved oxygen) data are being continuously recorded (Reuter et al. 2009).

Suspended particulate matter. Subsamples were filtered onto precombusted $\left(2 \mathrm{~h}, 450^{\circ} \mathrm{C}\right)$ and preweighed GF/F filters (Whatman). Filters were rinsed with distilled water to remove salt and kept frozen at $-20^{\circ} \mathrm{C}$ until gravimetric analysis as described in Lunau et al. (2006).

Chlorophyll $\boldsymbol{a}$ and phaeopigments. Subsamples of 0.5 to $1.0 \mathrm{l}$ were filtered onto GF/F filters (Whatman), immediately wrapped into aluminium foil and kept

Table 1. Days to new moon (NM), temperature and salinity at the inlet station in the back-barrier intertidal basin of Spiekeroog Island during tidal cycles in 2005

\begin{tabular}{|lcrcrc|}
\hline \multirow{2}{*}{ Date } & \multirow{2}{*}{\begin{tabular}{c}
\multicolumn{2}{c}{ Days } \\
to NM
\end{tabular}} & \multicolumn{2}{c|}{ Memperature $\left({ }^{\circ} \mathrm{C}\right)$} & \multicolumn{2}{c|}{ Salinity } \\
& & Mean & Range & Mean & Range \\
\hline 11-12 Jan & 27 & 7.25 & $6.90-7.40$ & 30.83 & $29.72-32.05$ \\
26-27 Apr & 11 & 9.91 & $8.85-10.80$ & 32.51 & $32.42-32.60$ \\
19-20 Jul & 16 & 19.69 & $18.65-20.09$ & 31.97 & $31.81-32.11$ \\
$16-17$ Nov & 13 & 8.85 & $7.80-9.75$ & 29.84 & $29.31-30.28$ \\
\hline
\end{tabular}
centrifuged (relative centrifugal force: $190 \mathrm{~g}$ ) to separate bacteria from other particulates. The supernatant was filtered through a black $0.2 \mu \mathrm{m}$ polycarbonate filter (Poretrics), stained with a SYBR Green I-moviol solution directly on a glass slide and enumerated thereafter. To determine total bacterial numbers, PA bacteria were detached from the particles by treatment with methanol and sonication and further processed in the same way as samples for FL bacteria (Lunau et al. 2005). Numbers of PA bacteria were calculated as the difference of total bacteria minus FL bacteria.

Bacterial biomass production. Rates of $\mathrm{BP}$ were determined by the incorporation of ${ }^{14} \mathrm{C}$-leucine (Simon \& Azam 1989). Triplicate $5 \mathrm{ml}$ subsamples and a formalin-killed control were incubated with ${ }^{14} \mathrm{C}$-leucine $(10.8 \mathrm{GBq}$ $\mathrm{mmol}^{-1}$, Hartmann Analytic, Germany) at a final concentration of $70 \mathrm{nM}$ in the dark at in situ temperature for $1 \mathrm{~h}$ on a plankton wheel to avoid sedimentation. Subsamples were fixed with formalin ( $2 \%$ final concentration), filtered onto $0.2 \mu \mathrm{m}$ cellulose nitrate filters (Sartorius) and further processed as described by Lunau et al. (2006). Bio- 
mass production was calculated according to Simon \& Azam (1989), assuming a 2-fold intracellular isotope dilution and applying a conversion factor of $3.15 \mathrm{~kg}$ protein per mol leucine. The bulk generation time of the bacterial community was calculated as the ratio of bacterial biomass to BP per day. Bacterial biomass was calculated from bacterial cell numbers assuming $20 \mathrm{fg}$ C cell-1 (Lee \& Fuhrman 1987).

Turnover and incorporation rates of DFAA. Turnover rate constants of DFAA were determined by measuring the incorporation of a mixture of $16{ }^{3} \mathrm{H}$-DFAA (mean specific activity 1.97 GBq milliatom C, TRK440, Amersham) by heterotrophic bacteria. ${ }^{3} \mathrm{H}$-DFAA were added to triplicate $5 \mathrm{ml}$ subsamples and a Formalinkilled control at a final concentration of $0.1 \mathrm{nmol}^{-1}$ of total DFAA. Incubations were further processed as for BP. Turnover rate constants of DFAA were calculated as the ratio of the radioactivity incorporated per hour to the radioactivity added. Incorporation rates of DFAA were determined by multiplying the DFAA turnover rate constant with measured DFAA concentrations (see above) and assuming $50 \mathrm{~g} \mathrm{C}$ per mol amino acid (Simon 1998). The CV of the triplicate measurements was usually $<15 \%$.

Normalized data. In order to detect recurrent tidal patterns irrespective of seasonal variations, we normalized the data according to the empirical model of Lunau et al. (2006). Therefore, values of a given parameter at each depth of one tidal cycle were calculated as the percentage of its tidal mean, and means of these numbers were calculated for the data set of the tidal cycles in 2005 for all 3 depths.
Correlation analysis. A correlation analysis of the parameters assessed was performed using the Pearson Product-Moment Correlation tool of the SigmaStat Software (Version 2.0.3, Systat Software).

\section{RESULTS}

Pronounced differences of sea surface temperature, salinity (Table 1), SPM, chl a and phaeopigments (Table 2) reflected the various seasons in which the tidal cycles were studied. Mean temperatures of the tidal cycles ranged between $\sim 7^{\circ} \mathrm{C}$ in January and $\sim 19^{\circ} \mathrm{C}$ in July, and salinities between 29.31 and 32.60 in November and April, respectively. The water column was never stratified. Temperature and salinity variations during the tidal cycles were minor except in January for salinity. The water column was undersaturated with oxygen in the tidal cycles in January, July, and November. During the tidal cycle in January, saturation ranged between 86 and $89 \%$ and during those in July and November from 91 to $99 \%$ and 88 to $97 \%$, respectively (Fig. 2). The water column was only oxygen-supersaturated, from 101 to $108 \%$, during the day in April. However, during the late night and early morning between outgoing and incoming mean tide, oxygen saturation was only 95 to $97 \%$ (data not shown). SPM and phaeopigments exhibited highest tidal means in January and November while chl $a$ and rates of BP peaked in April and July. Numbers of FL and PA bacteria were lower in January and April relative to July and November

Table 2. Means, minima and maxima of suspended particulate matter (SPM), chlorophyll a (chl a) and phaeopigments (concentration and \% of total chlorophyll) in the surface, mid-depth, and bottom layer of the tidal cycles assessed in January, April, July and November 2005 at the inlet of the main tidal channel of the Spiekeroog intertidal flat system

\begin{tabular}{|c|c|c|c|c|c|c|c|c|}
\hline \multirow{2}{*}{$\begin{array}{l}\text { Date } \\
\text { Water layer }\end{array}$} & \multicolumn{2}{|c|}{$\mathrm{SPM}\left(\mathrm{mg} \mathrm{l}^{-1}\right)$} & \multicolumn{2}{|c|}{ Chl a $\left(\mu g l^{-1}\right)$} & \multicolumn{2}{|c|}{ Phaeopigments $\left(\mu \mathrm{g}^{-1}\right)$} & \multicolumn{2}{|c|}{ Phaeopigments (\% chl) } \\
\hline & Mean & $(\min -\max )$ & Mean & $(\min -\max )$ & Mean & $(\min -\max )$ & Mean & $(\min -\max )$ \\
\hline \multicolumn{9}{|c|}{ 11-12 January } \\
\hline Surface & 72.9 & $(38.0-127.0)$ & 2.2 & $(1.2-3.3)$ & 6.0 & $(2.9-9.6)$ & 71.1 & $(60.3-88.9)$ \\
\hline Mid-depth & 88,4 & $(31.2-158.6)$ & 2.5 & $(1.2-4.0)$ & 6.1 & $(2.7-10.1)$ & 70.5 & $(61.5-76.4)$ \\
\hline Bottom & 101.7 & $(32.2-175.2)$ & 2.7 & $(1.7-4.6)$ & 6.2 & $(1.8-9.5)$ & 67.7 & $(27.7-75.1)$ \\
\hline \multicolumn{9}{|l|}{ 26-27 April } \\
\hline Surface & 24.5 & $(8.0-58.0)$ & 4.8 & $(3.2-6.4)$ & 1.6 & $(0.6-2.0)$ & 24.9 & $(13.3-33.2)$ \\
\hline Mid-depth & 27.9 & $(6.8-71.6)$ & 5.1 & $(3.8-6.6)$ & 1.9 & $(1.0-2.5)$ & 26.3 & $(21.7-31.0)$ \\
\hline Bottom & 31.9 & $(7.0-69.2)$ & 5.4 & $(3.4-7.1)$ & 2.1 & $(1.0-3.7)$ & 27.6 & $(19.9-34.9)$ \\
\hline \multicolumn{9}{|l|}{ 19-20 July } \\
\hline Surface & 19.6 & $(7.5-36.8)$ & 5.0 & $(3.1-6.7)$ & 3.1 & $(0.3-5.1)$ & 35.8 & $(7.6-54.1)$ \\
\hline Mid-depth & 25.6 & $(7.8-50.0)$ & 5.2 & $(2.8-7.0)$ & 3.7 & $(0.7-5.9)$ & 40.1 & $(16.2-50.9)$ \\
\hline Bottom & 44.5 & $(8.1-112.2)$ & 6.0 & $(3.4-8.7)$ & 5.7 & $(1.0-12.2)$ & 44.7 & $(21.2-58.4)$ \\
\hline \multicolumn{9}{|c|}{ 16-17 November } \\
\hline Surface & 46.5 & $(21.0-64.8)$ & 2.1 & $(1.7-2.9)$ & 5.1 & $(1.8-7.5)$ & 69.2 & $(50.3-77.1)$ \\
\hline Mid-depth & 55.5 & $(25.2-81.4)$ & 2.0 & $(1.1-2.8)$ & 6.3 & $(2.7-9.7)$ & 75.0 & $(61.7-82.0)$ \\
\hline Bottom & 61.6 & $(43.0-76.8)$ & 2.4 & $(1.7-3.1)$ & 6.9 & $(4.9-8.6)$ & 74.4 & $(67.9-82.8)$ \\
\hline
\end{tabular}



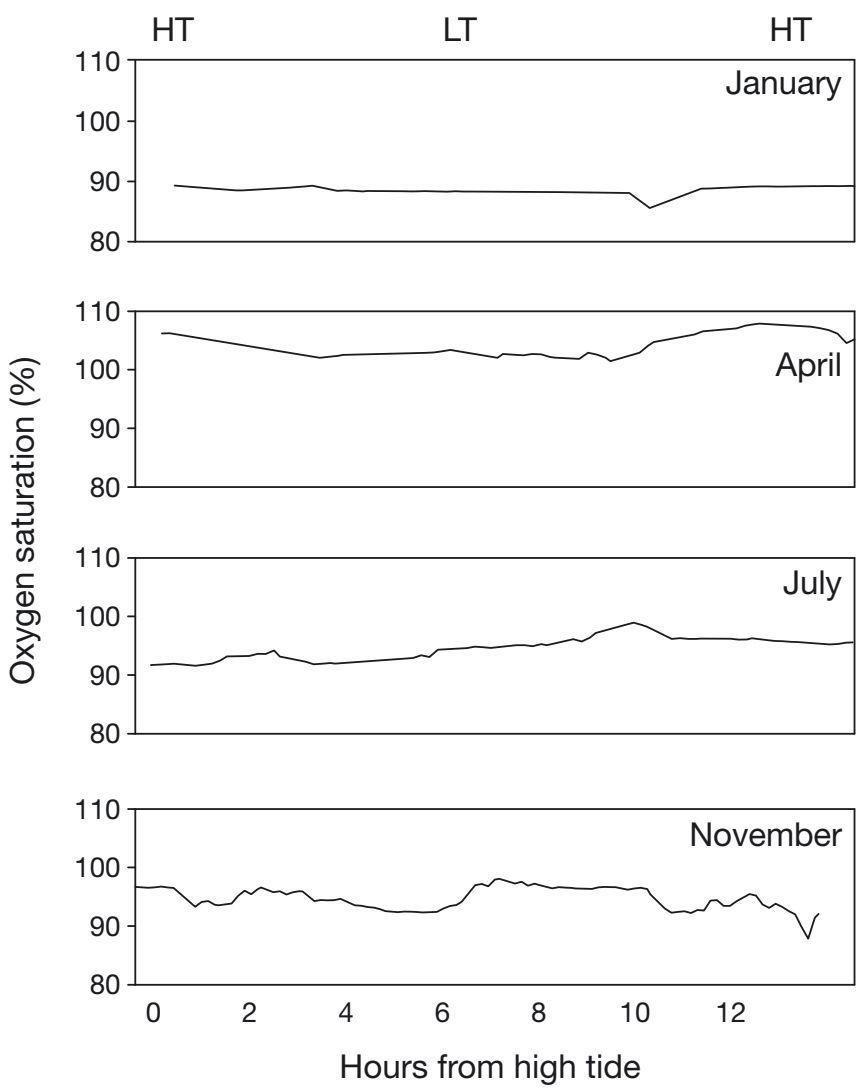

Fig. 2. Tidal patterns of dissolved oxygen (\% saturation) on 11-12 January, 26-27 April, 19-20 July, and 16-17 November 2005 at $2 \mathrm{~m}$ depth at the inlet of the main channel of the intertidal flat system of Spiekeroog Island, German Wadden Sea. HT: high tide; LT: low tide

(Table 3, Fig. 3). In contrast, DFAA concentrations were higher in January and April than in July and November. DFAA turnover rate constants were lower in November than during the previous tidal cycles (Fig. 3). DFAA turnover rate constants varied with tide and were highest in January, then decreased in the other sampled months. DFAA incorporation rates were highest in January and April.

During the tidal cycle in January, SPM (Table 2, tidal patterns of SPM not shown), chl a and DFAA turnover rate constants peaked around outgoing mean tide and $1 \mathrm{~h}$ before incoming mean tide and exhibited distinct minima $1 \mathrm{~h}$ after slack water and in particular at low tide (Fig. 3). Numbers of PA bacteria and rates of $\mathrm{BP}$ were also enhanced around mean tide but not as much as the former parameters. Concentrations of chl $a$ and rates of BP and DFAA turnover at the surface were lower than at mid-depth and bottom from low tide to incoming mean tide. DFAA concentrations fluctuated largely but did not covary with the tidal current patterns. These tidal covariations were

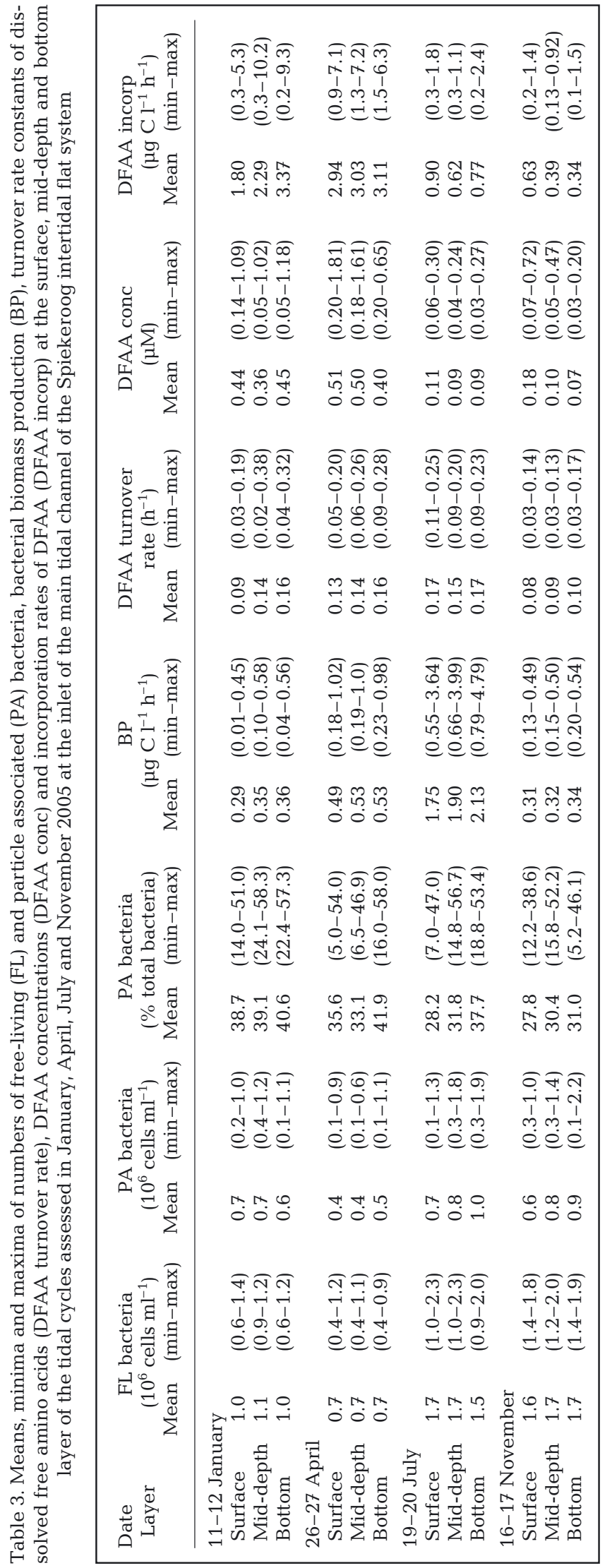



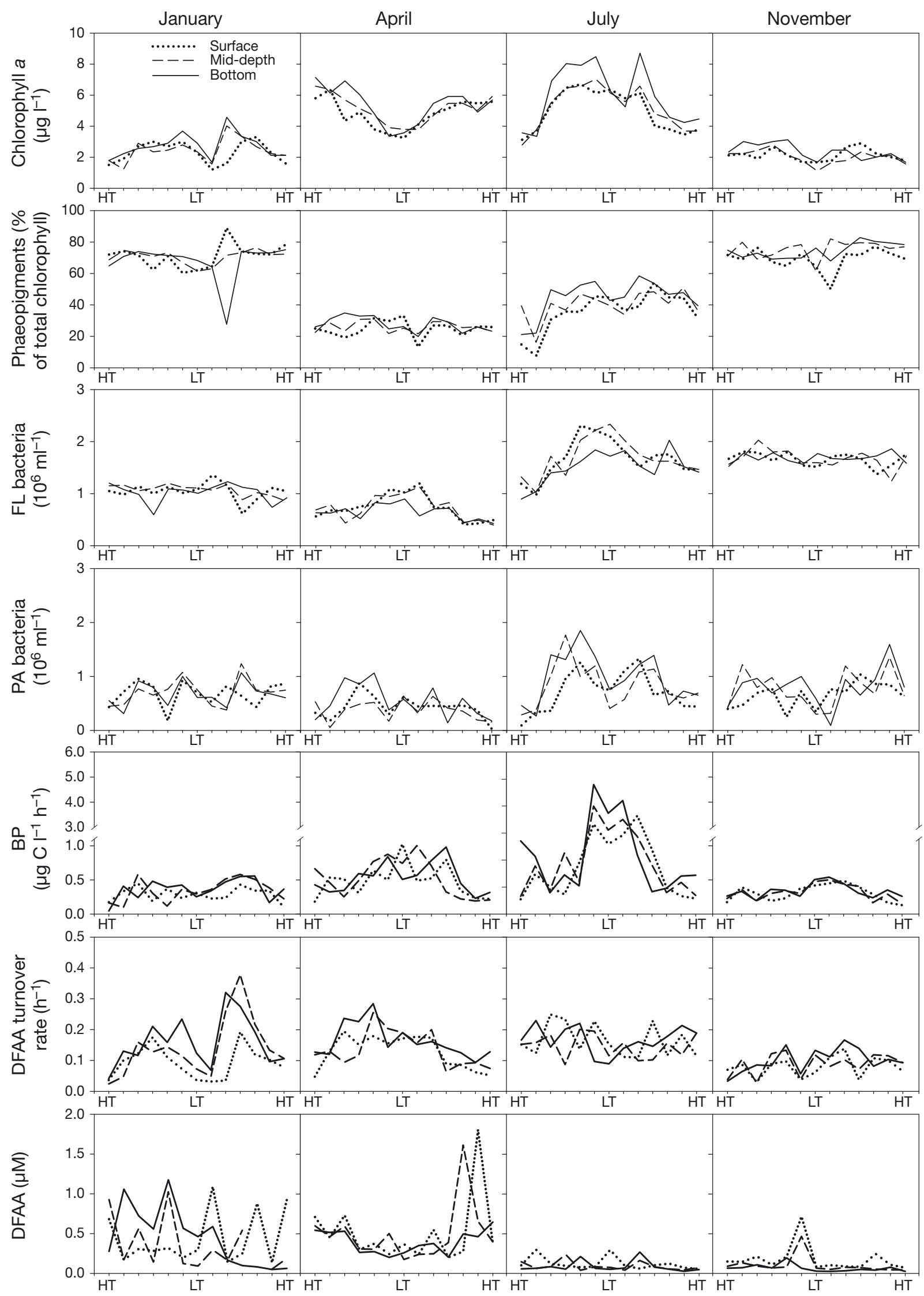
Fig. 3. Tidal patterns of chlorophyll $a$, phaeopigments, freeliving (FL) and particle-associated (PA) bacteria, bacterial biomass production (BP), turnover rate and concentration of dissolved free amino acids (DFAA) on 11-12 January, 26-27 April, 19-20 July, and 16-17 November 2005 at the surface, mid-depth and bottom at the inlet of the main channel of the intertidal flat system of Spiekeroog Island, German Wadden Sea. Note the breaks of the $y$-axes in the BP panels of January, April and November but not of July; HT: high tide; LT: low tide

substantiated by significant positive correlations (Table 4). Most correlations existed for mid-depth. Numbers of FL bacteria changed little over the tidal cycle or vertically in the water column; distinct minima of FL bacteria abundance occurred only at outgoing tide at the bottom and at incoming tide at the surface (Fig. 3). At the surface, numbers of total bacteria were correlated to those of FL bacteria, but at mid-depth and the bottom they were correlated to those of PA bacteria (Table 4). Percent phaeopigments of total chlorophyll also changed little over the tidal cycle and vertically except $2 \mathrm{~h}$ after low tide at the surface and the bottom (Fig. 3).

During the spring bloom in April, chl a exhibited minima at low tide and enhanced concentrations around mean tide, in particular at the bottom (Fig. 3), due to rapid aggregation and sedimentation of suspended organic matter (Lemke et al. 2009). SPM and phaeopigment concentrations covaried with chl $a$, most closely at mid-depth and the bottom, as indicated by significant positive correlations (Table 4). Phaeopigments comprised the lowest percentage of total chlorophyll in April (Table 2, Fig. 3). The percentage remained approximately constant during the tidal cycle, but a distinct minimum occurred $1 \mathrm{~h}$ after low tide. In contrast to chl $a$, numbers of FL bacteria were enhanced from $1 \mathrm{~h}$ after outgoing mean tide to $1 \mathrm{~h}$ after low tide, in particular at the surface and mid-depth (Fig. 3). This inverse covariation was substantiated by the negative correlation between FL

Table 4. Correlation analysis of free-living (FL), particle-associated (PA) and total bacteria, suspended particulate matter (SPM), chlorophyll a (chl a), phaeopigment concentration (Phaeo) and \% of total chlorophyll (Phaeo \% chl), dissolved free amino acids concentration (DFAA), DFAA turnover rate (DFAA-Tr), and bacterial biomass production (BP) in the surface, mid-depth, and bottom water layer at the inlet of the Spiekeroog intertidal flat system during the tidal cycles on 11-12 January (above the diagonals) and on 26-27 April 2005 (below the diagonals). Given are significant correlation coefficients of a Pearson Product-Moment analysis $(\mathrm{p}<0.05)$. ns: not significant

\begin{tabular}{|c|c|c|c|c|c|c|c|c|c|c|}
\hline Depth & Parameter & $\begin{array}{c}\text { FL } \\
\text { bacteria }\end{array}$ & $\begin{array}{c}\text { PA } \\
\text { bacteria }\end{array}$ & $\begin{array}{c}\text { Total } \\
\text { bacteria }\end{array}$ & SPM & Chl a & Phaeo & DFAA & DFAA-Tr & $\mathrm{BP}$ \\
\hline \multirow[t]{9}{*}{ Surface } & FL bacteria & $\mathrm{X}$ & ns & 0.59 & -0.70 & ns & ns & ns & -0.69 & ns \\
\hline & PA bacteria & ns & $x$ & 0.80 & $\mathrm{~ns}$ & ns & ns & ns & ns & ns \\
\hline & Total bacteria & ns & 0.76 & $\mathrm{X}$ & -0.64 & ns & ns & ns & ns & ns \\
\hline & SPM & ns & ns & -0.77 & $\mathrm{X}$ & 0.74 & ns & ns & 0.77 & ns \\
\hline & Chl a & -0.76 & ns & ns & 0.55 & $x$ & ns & ns & 0.73 & ns \\
\hline & Phaeo & -0.57 & ns & -0.55 & ns & $\mathrm{ns}$ & $x$ & ns & $\mathrm{ns}$ & ns \\
\hline & DFAA & $\mathrm{ns}$ & $\mathrm{ns}$ & $\mathrm{ns}$ & ns & ns & ns & $\mathrm{X}$ & ns & ns \\
\hline & DFAA-Tr & 0.70 & ns & 0.75 & ns & -0.72 & -0.65 & ns & X & ns \\
\hline & $\mathrm{BP}$ & 0.56 & & 0.56 & ns & -0.60 & ns & ns & 0.55 & $x$ \\
\hline \multirow[t]{9}{*}{ Mid-depth } & FL bacteria & $\mathrm{X}$ & ns & ns & ns & ns & ns & ns & ns & ns \\
\hline & PA bacteria & ns & $X$ & 0.89 & ns & ns & ns & ns & ns & ns \\
\hline & Total bacteria & 0.84 & 0.72 & $\mathrm{X}$ & ns & ns & ns & ns & ns & ns \\
\hline & SPM & ns & ns & ns & $\mathrm{x}$ & 0.87 & 0.91 & $\mathrm{~ns}$ & 0.75 & 0.61 \\
\hline & Chl a & -0.65 & ns & -0.60 & 0.64 & $x$ & ns & $\mathrm{ns}$ & 0.82 & 0.73 \\
\hline & Phaeo & ns & ns & ns & 0.77 & 0.79 & $\mathrm{x}$ & ns & 0.90 & 0.70 \\
\hline & DFAA & -0.55 & ns & ns & ns & ns & ns & $x$ & ns & ns \\
\hline & DFAA-Tr & 0.70 & ns & 0.71 & -0.61 & ns & ns & ns & $x$ & 0.73 \\
\hline & $\mathrm{BP}$ & 0.89 & $\mathrm{~ns}$ & 0.81 & -0.63 & ns & ns & $\mathrm{ns}$ & ns & $x$ \\
\hline \multirow[t]{10}{*}{ Bottom } & FL bacteria & $X$ & ns & ns & ns & ns & ns & ns & ns & ns \\
\hline & PA bacteria & ns & $x$ & 0.79 & ns & ns & 0.70 & ns & ns & ns \\
\hline & Total bacteria & 0.64 & 0.93 & $\mathrm{x}$ & ns & ns & ns & ns & ns & ns \\
\hline & SPM & ns & ns & ns & $\mathrm{x}$ & 0.95 & ns & ns & ns & ns \\
\hline & Chl a & ns & ns & ns & 0.69 & $x$ & ns & ns & 0.92 & 0.58 \\
\hline & Phaeo & ns & ns & ns & 0.71 & 0.74 & $\mathrm{X}$ & ns & ns & ns \\
\hline & Phaeo (\% chl) & ns & 0.71 & 0.72 & $\mathrm{~ns}$ & ns & ns & ns & ns & ns \\
\hline & DFAA & -0.62 & ns & ns & ns & 0.60 & ns & $x$ & ns & ns \\
\hline & DFAA-Tr & ns & 0.84 & 0.86 & ns & ns & ns & ns & $x$ & ns \\
\hline & $\mathrm{BP}$ & $\mathrm{ns}$ & ns & ns & ns & 0.56 & 0.61 & $\mathrm{~ns}$ & ns & $x$ \\
\hline
\end{tabular}


bacteria abundance and concentrations of chl a and phaeopigments (Table 4). Numbers of PA bacteria showed some tidal variations, but without clear tidal patterns (Fig. 3), and were correlated to total bacterial numbers (Table 4). DFAA concentrations fluctuated greatly but not in relation to the tidal currents and without clear vertical patterns. Rates of BP were mainly enhanced from outgoing to incoming mean tide but values at the 3 depths did not covary. DFAA turnover rate constants increased shortly after high tide at the surface and bottom and decreased at incoming mean tide at the surface and mid-depth. At these depths, rates of BP and DFAA turnover were correlated to numbers of FL bacteria. In contrast, the DFAA turnover rate constant at the bottom was correlated to numbers of PA and total bacteria while BP was correlated to chl a (Table 4). These correlations indicate that from the surface to mid-depth, FL bacteria were mainly mediating the organic matter turnover, whereas towards the bottom, this was true for PA bacteria.
The tidal cycle in July was characterized by the highest concentrations of chl $a$ and the highest rates of BP, in particular at the bottom (Table 3, Fig. 3). Chl a concentrations, percent phaeopigments and numbers of PA bacteria exhibited distinct minima at low and high tide. Numbers of FL bacteria and rates of BP were also low at high tide but reached maxima from $2 \mathrm{~h}$ before to $2 \mathrm{~h}$ after low tide. During this period, numbers of FL bacteria were much higher at the surface and mid-depth than at the bottom, whereas rates of BP continuously increased from surface to bottom (Fig. 3). DFAA concentrations were much lower than in January and April, and exhibited only minor tidal fluctuations. Parameters characterizing the particulate phase and numbers of FL, PA and total bacteria exhibited significant positive correlations between each other throughout the water column in July (Table 5). At the bottom, however, FL bacteria were only correlated to total bacteria and percent phaeopigments. At the surface, rates of BP were correlated to the parameters characterizing the particulate phase and PA bacteria,

Table 5. Correlation analysis of the given parameters at the surface, mid-depth and bottom water layers at the inlet of the Spiekeroog intertidal flat system during the tidal cycles on 19-20 July 2005 (above the diagonals) and 16-17 November 2005 (below the diagonals). Given are significant correlation coefficients of a Pearson Product-Moment analysis ( $p<0.05)$. ns: not significant; further definitions as in Table 4

\begin{tabular}{|c|c|c|c|c|c|c|c|c|c|c|c|}
\hline Depth & Parameter & $\begin{array}{c}\text { FL } \\
\text { bacteria }\end{array}$ & $\begin{array}{c}\text { PA } \\
\text { bacteria }\end{array}$ & $\begin{array}{c}\text { Total } \\
\text { bacteria }\end{array}$ & SPM & Chl a & Phaeo & $\begin{array}{l}\text { Phaeo } \\
\text { (\% chl) }\end{array}$ & DFAA & DFAA-Tr & $\mathrm{BP}$ \\
\hline \multirow[t]{10}{*}{ Surface } & FL bacteria & $x$ & 0.64 & 0.91 & 0.61 & 0.70 & 0.84 & 0.68 & ns & ns & $\mathrm{ns}$ \\
\hline & PA bacteria & $\mathrm{ns}$ & $x$ & 0.90 & 0.67 & 0.78 & 0.66 & $\mathrm{~ns}$ & $\mathrm{~ns}$ & $\mathrm{~ns}$ & 0.66 \\
\hline & Total bacteria & ns & 0.91 & $x$ & 0.70 & 0.82 & 0.83 & 0.63 & ns & ns & 0.63 \\
\hline & SPM & ns & $\mathrm{ns}$ & ns & $\mathrm{X}$ & 0.85 & 0.78 & ns & ns & ns & 0.76 \\
\hline & Chl a & ns & ns & ns & 0.80 & $x$ & 0.66 & ns & ns & ns & 0.56 \\
\hline & Phaeo & ns & ns & 0.70 & ns & 0.56 & $x$ & ns & ns & ns & 0.66 \\
\hline & Phaeo (\% chl) & ns & ns & ns & 0.72 & ns & ns & $x$ & ns & ns & ns \\
\hline & DFAA & ns & ns & ns & ns & ns & ns & ns & $x$ & ns & ns \\
\hline & DFAA-Tr & ns & ns & ns & ns & ns & ns & ns & ns & $x$ & ns \\
\hline & $\mathrm{BP}$ & ns & ns & ns & ns & ns & ns & ns & ns & ns & $x$ \\
\hline \multirow[t]{10}{*}{ Mid-depth } & FL bacteria & $x$ & ns & 0.70 & 0.65 & 0.69 & 0.66 & ns & ns & ns & $\mathrm{ns}$ \\
\hline & PA bacteria & ns & $x$ & 0.76 & 0.60 & 0.65 & 0.59 & ns & ns & ns & ns \\
\hline & Total bacteria & ns & 0.94 & $x$ & 0.84 & 0.91 & 0.85 & ns & ns & ns & 0.55 \\
\hline & SPM & ns & 0.73 & 0.75 & $\mathrm{X}$ & 0.91 & 0.87 & ns & ns & ns & 0.66 \\
\hline & Chl a & ns & ns & 0.62 & 0.63 & $x$ & 0.79 & ns & ns & ns & ns \\
\hline & Phaeo & ns & ns & ns & ns & ns & $x$ & ns & ns & ns & ns \\
\hline & Phaeo (\% chl) & ns & ns & ns & 0.65 & ns & ns & $\mathrm{X}$ & ns & ns & ns \\
\hline & DFAA & ns & ns & ns & ns & ns & ns & ns & $\mathrm{x}$ & ns & ns \\
\hline & DFAA-Tr & ns & ns & ns & ns & ns & ns & ns & ns & $x$ & ns \\
\hline & $\mathrm{BP}$ & ns & ns & ns & ns & ns & ns & ns & ns & ns & $x$ \\
\hline \multirow[t]{10}{*}{ Bottom } & FL bacteria & $x$ & ns & 0.69 & ns & ns & ns & 0.67 & ns & ns & ns \\
\hline & PA bacteria & ns & $x$ & 0.88 & 0.79 & 0.85 & 0.82 & 0.75 & ns & ns & ns \\
\hline & Total bacteria & 0.58 & 0.99 & $\mathrm{X}$ & 0.71 & 0.83 & 0.82 & 0.90 & ns & ns & ns \\
\hline & SPM & ns & ns & ns & $\mathrm{X}$ & 0.94 & 0.96 & 0.71 & 0.72 & 0.58 & ns \\
\hline & Chl a & ns & ns & ns & 0.57 & $x$ & 0.94 & 0.77 & 0.60 & ns & ns \\
\hline & Phaeo & ns & ns & ns & 0.80 & ns & $x$ & ns & 0.69 & 0.56 & ns \\
\hline & Phaeo (\% chl) & ns & ns & ns & ns & -0.72 & ns & $X$ & ns & ns & ns \\
\hline & DFAA & ns & ns & ns & 0.57 & 0.66 & ns & ns & $\mathrm{X}$ & ns & ns \\
\hline & DFAA-Tr & ns & ns & ns & ns & ns & ns & ns & ns & $x$ & -0.63 \\
\hline & $\mathrm{BP}$ & ns & ns & ns & ns & ns & ns & ns & ns & ns & $x$ \\
\hline
\end{tabular}


but at mid-depth, correlations only occurred with total bacteria and SPM; at the bottom, such correlations did not exist. The turnover rate constant of DFAA exhibited tidal variations but no clear tidal patterns and no covariations to other parameters were observed. Only at the bottom was the DFAA turnover rate constant correlated to $\mathrm{BP}$, and this correlation was inversed (Table 5).

In November, chl $a$, rates of BP and DFAA turnover exhibited much lower values than in July, whereas numbers of FL and PA bacteria remained high, and concentrations of phaeopigments were even higher than in July (Tables 2 \& 3, Fig. 3). Tidal variations were lower than in April and July. However, chl a concentrations, percent phaeopigments, numbers of PA bacteria and DFAA turnover rate constants exhibited consistent minima around low tide, whereas rates of BP were enhanced. DFAA concentrations fluctuated little and remained below $200 \mathrm{nM}$ except $1 \mathrm{~h}$ before low tide when peaks occurred at the surface and mid-depth, simultaneously with minima of DFAA turnover rate constants (Fig. 3). Fewer covariations existed between parameters of the particulate phase and bacteria and none between bacterial numbers and BP rates and parameters characterizing the particulate phase (Table 5).

Mean bacterial generation times at the 3 depths ranged from 3.8 to $4.9 \mathrm{~d}$ in January, from 1.7 to $2.0 \mathrm{~d}$ in April, from 0.8 to $1.1 \mathrm{~d}$ in July, and from 6.1 to $7.5 \mathrm{~d}$ in November. Daily BP was calculated by integrating the hourly values at single tidal situations and depths over the water column and over the tidal cycle, assuming 1.92 tidal cycles per day, and yielded $136.2 \mathrm{mg} \mathrm{C} \mathrm{m}^{-2}$ $\mathrm{d}^{-1}$ for January, $211.5 \mathrm{mg} \mathrm{C} \mathrm{m}^{-2} \mathrm{~d}^{-1}$ for April, $784.7 \mathrm{mg}$ $\mathrm{C} \mathrm{m}^{-2} \mathrm{~d}^{-1}$ for July and $130.8 \mathrm{mg} \mathrm{C} \mathrm{m}^{-2} \mathrm{~d}^{-1}$ for November; thus, daily BP varied 6-fold throughout the year.

Tidal means of DFAA incorporation rates in January and April ranged from 1.8 to $3.37 \mu \mathrm{g} \mathrm{Cl}^{-1} \mathrm{~h}^{-1}$, accounting for $572 \%$ to $936 \%$ of BP and thus greatly exceeded rates of BP (Table 3). In July and November, tidal means of DFAA incorporation varied from 0.34 to $0.90 \mu \mathrm{g} \mathrm{C}^{-1} \mathrm{~h}^{-1}$, accounting for 36 to $51 \%$ and 100 to $203 \%$ of $\mathrm{BP}$, respectively.

In order to identify and elucidate general tidal patterns of the parameters assessed during the 4 tidal cycles, we applied the empirical model of Lunau et al. (2006) to normalize the data on the basis of their tidal means and deviations in the course of the tide. This normalization revealed maxima, i.e. enhanced values relative to the tidal mean, of SPM, chl $a$, phaeopigments, PA bacteria and DFAA turnover rate constants around mean tide and at high current velocities at all 3 depths, and reduced values shortly after low tide and at high tide (Fig. 4). Maxima and minima were most pronounced for SPM and PA bac- teria. These covariations were substantiated by significant positive correlations of several parameters at all 3 depths (Table 6). A significant correlation to the current velocity, however, existed only for chl a (surface: $r=0.64$; mid-depth: $r=0.56$; bottom: $r=0.60$; $\mathrm{p}<0.05$ ) and the DFAA turnover rate constant at the surface $(r=0.75 ; \mathrm{p}<0.05)$. In contrast to these distinct patterns, numbers of FL bacteria remained nearly constant during the tidal cycle. Dynamics were most pronounced at the bottom with reductions down to $80 \%$ of the tidal mean around mean tide. Rates of BP exhibited unique tidal patterns with a distinct maximum from $1 \mathrm{~h}$ after outgoing to $1 \mathrm{~h}$ before incoming tide. Interestingly, numbers of FL bacteria at the surface were significantly correlated to numbers of PA and total bacteria, percent phaeopigments and rates of BP (Table 6). At mid-depth, however, numbers of FL bacteria were only correlated to rates of $\mathrm{BP}$, and at the bottom, no correlation to other parameters existed. Both at the bottom and at mid-depth, rates of BP were correlated to phaeopigments. DFAA concentrations exhibited tidal fluctuations that were independent of the water current patterns.

\section{DISCUSSION}

Relatively little is known about tidal patterns of microbial organic matter processing and BP, despite detailed information on tidal patterns of SPM. Among the few investigations which measured BP in intertidal flat ecosystems, only Poremba et al. (1999) and Grossart et al. (2004) examined BP in the course of tidal cycles. The bacterial turnover of amino acids, one of the most important substrates for BP (Berman \& Bronk 2003), has not yet been studied in intertidal flat ecosystems.

Our results show pronounced tidal patterns and seasonal and vertical differences of all parameters characterizing the bacterial organic matter turnover as a response to those of SPM-associated parameters. Phytoplankton biomass and bacterial numbers, production and DFAA turnover were higher in April and July than in January and November. In particular in April and July, pronounced vertical differences existed with an increasing intensity of bacterial decomposition processes towards the bottom. This was evident from the BP data as a bacterial response to enhanced concentrations of chl $a$ and phaeopigments near the bottom. Bacterial organic matter turnover towards the bottom was increasingly associated with the particulate phase, as reflected by higher numbers of PA bacteria, while numbers of FL bacteria simultaneously decreased. 


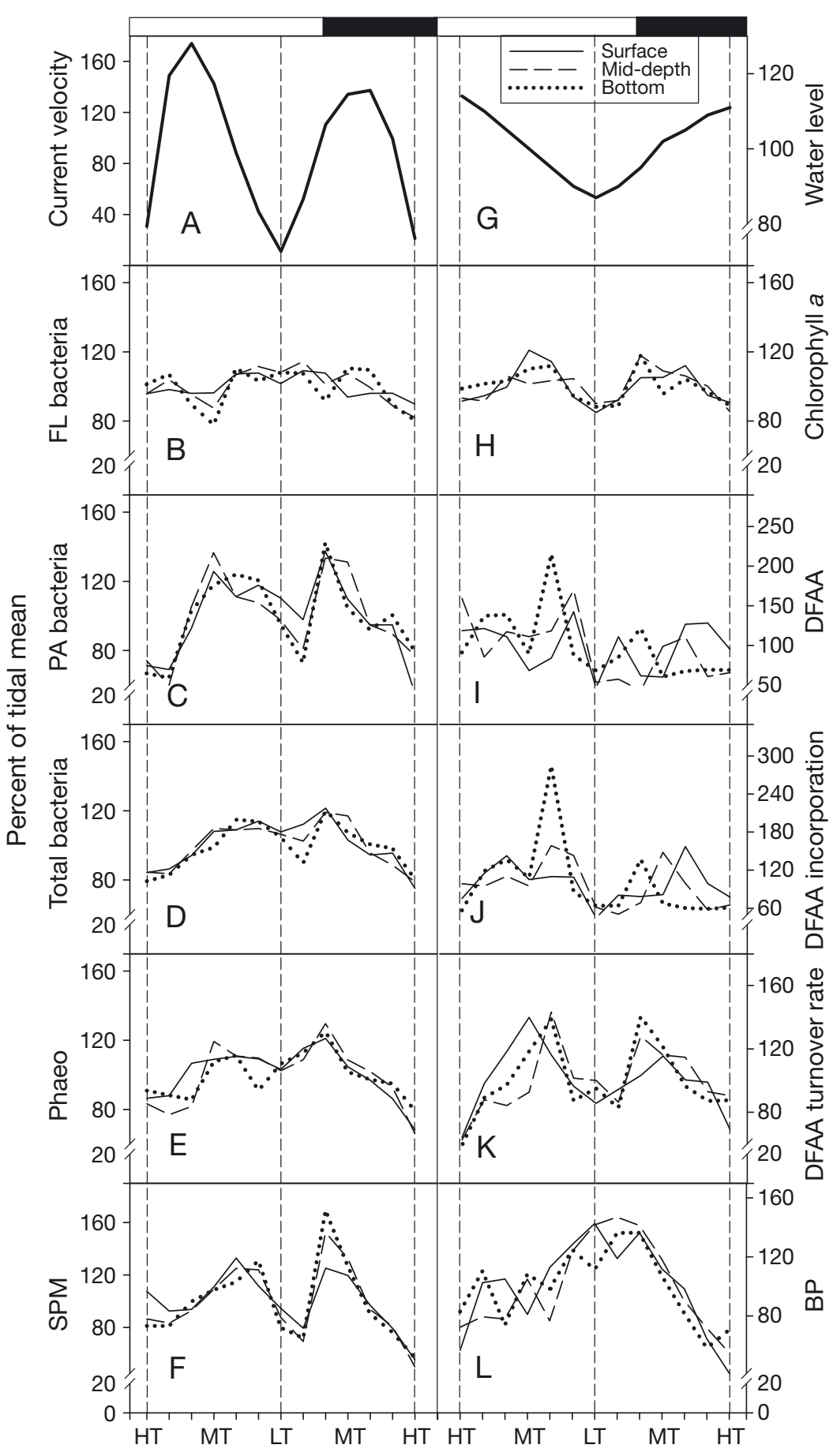

Fig. 4. Normalized tidal patterns of the (A) current velocity, (B) free-living (FL) bacteria, (C) particle-associated (PA) bacteria, (D) total bacterial numbers, (E) phaeopigment percentage of total chlorophyll (Phaeo), (F) suspended particulate matter (SPM), (G) water level, (H) chlorophyll $a_{\text {, }}(\mathrm{I})$ concentrations of dissolved free amino acids (DFAA), (J) DFAA incorporation, (K) DFAA turnover rate constant and (L) bacterial biomass production (BP) at the surface, mid-depth and bottom at the inlet of the main channel of the intertidal flat system of Spiekeroog Island, German Wadden Sea. Black and white bars on top indicate night and day periods, respectively. Data of the tidal cycle were normalized as percent of their tidal mean according to Lunau et al. (2006). HT: high tide; MT: mean tide; LT: low tide
The existence of tidal patterns of SPM, POC, suspended aggregates, chl $a$, phaeopigments, BP, and bacterial numbers has been shown in several studies in the Wadden Sea, the largest intertidal flat ecosystem globally (e.g. van Leussen 1996, Poremba et al. 1999, Grossart et al. 2004, Lunau et al. 2006, Bartholomä et al. 2009). These tidal patterns are driven by the current field and resuspension and vary seasonally and according to the ambient hydrodynamic conditions. Regular tidal patterns of SPM-associated parameters, total bacterial numbers and DOC, on the basis of normalized tidal patterns and irrespective of the seasonal tidal variabilities, have been identified by Lunau et al. (2006). The results of the present study extend these findings by showing that these patterns exist in the entire water column of a tidal channel, with only slight vertical differences. In addition, our results demonstrate that numbers of PA bacteria, rates of BP and DFAA turnover also exhibit regular tidal patterns. Normalized tidal patterns of numbers of PA bacteria and DFAA turnover rate constants correlated closely with SPM, phaeopigments and chl a. In contrast, normalized tidal patterns of BP rates at the surface correlated to numbers of FL and total bacteria, and at mid-depth to FL bacteria and phaeopigments. The latter are a proxy of senescent algae (Lucas \& Holligan 1999) and thus of readily decomposable particulate organic matter (POM, Table 6). Rates of BP at the bottom also correlated to phaeopigments. Our results further show that tidal minima of SPMassociated parameters occurred around low and high tide, indicating settling of particulates at low current velocities, and maxima occurred around mean tide, as a result of resuspension. These maxima were more pronounced at mid-depth and the bottom than at the surface and/or shifted $1 \mathrm{~h}$ further towards low tide; thus lagging behind the current velocity maximum and peaking at the surface at outgoing tide due to a more rapid clearing of settling material near the surface. At incoming tide, maxima of SPM-associated parameters occurred earlier at mid-depth and the bottom than at the surface because of increasing concentrations of 
Table 6. Correlation analysis of the normalized parameters at the surface, mid-depth and bottom water layers at the inlet of the Spiekeroog intertidal flat system. Given are significant correlation coefficients of a Pearson Product-Moment analysis $(\mathrm{p}<0.05)$. ns: not significant; further definitions as in Table 4

\begin{tabular}{|c|c|c|c|c|c|c|c|c|c|c|}
\hline Depth & Parameter & $\begin{array}{c}\text { PA } \\
\text { bacteria }\end{array}$ & $\begin{array}{c}\text { Total } \\
\text { bacteria }\end{array}$ & SPM & Chl a & Phaeo & $\begin{array}{l}\text { Phaeo } \\
\text { (\% chl) }\end{array}$ & DFAA & DFAA-Tr & $\mathrm{BP}$ \\
\hline Surface & $\begin{array}{l}\text { FL bacteria } \\
\text { PA bacteria } \\
\text { Total bacteria } \\
\text { SPM } \\
\text { Chl a } \\
\text { Phaeo } \\
\text { Phaeo (\% chl) } \\
\text { DFAA } \\
\text { DFAA-Tr } \\
\text { BP }\end{array}$ & $\begin{array}{c}0.59 \\
X\end{array}$ & $\begin{array}{c}0.61 \\
0.94 \\
X\end{array}$ & $\begin{array}{c}\mathrm{ns} \\
0.70 \\
0.61 \\
\mathrm{X}\end{array}$ & $\begin{array}{c}\mathrm{ns} \\
\mathrm{ns} \\
\mathrm{ns} \\
0.57 \\
\mathrm{X}\end{array}$ & $\begin{array}{c}\mathrm{ns} \\
0.60 \\
\mathrm{~ns} \\
0.76 \\
0.77 \\
\mathrm{X}\end{array}$ & $\begin{array}{c}0.75 \\
0.87 \\
0.93 \\
0.67 \\
\mathrm{~ns} \\
\mathrm{~ns} \\
\mathrm{X}\end{array}$ & $\begin{array}{c}\text { ns } \\
\text { ns } \\
\text { ns } \\
\text { ns } \\
\text { ns } \\
\text { ns } \\
\text { ns } \\
\text { X }\end{array}$ & $\begin{array}{c}\text { ns } \\
0.64 \\
\text { ns } \\
\text { ns } \\
0.79 \\
\text { ns } \\
\text { ns } \\
\text { ns } \\
\text { X }\end{array}$ & $\begin{array}{c}0.74 \\
\mathrm{~ns} \\
0.80 \\
\mathrm{~ns} \\
\mathrm{~ns} \\
\mathrm{~ns} \\
\mathrm{~ns} \\
\mathrm{~ns} \\
\mathrm{~ns} \\
\mathrm{X}\end{array}$ \\
\hline Mid-depth & $\begin{array}{l}\text { FL bacteria } \\
\text { PA bacteria } \\
\text { Total bacteria } \\
\text { SPM } \\
\text { Chl a } \\
\text { Phaeo } \\
\text { Phaeo (\% chl) } \\
\text { DFAA } \\
\text { DFAA-Tr } \\
\text { BP }\end{array}$ & $\begin{array}{c}\mathrm{ns} \\
\mathrm{X}\end{array}$ & $\begin{array}{c}\mathrm{ns} \\
0.87 \\
\mathrm{X}\end{array}$ & $\begin{array}{c}\mathrm{ns} \\
0.80 \\
0.84 \\
\mathrm{X}\end{array}$ & $\begin{array}{c}\text { ns } \\
0.77 \\
0.70 \\
0.87 \\
\text { X }\end{array}$ & $\begin{array}{c}\text { ns } \\
\text { ns } \\
\text { ns } \\
\text { ns } \\
\text { ns } \\
\text { X }\end{array}$ & $\begin{array}{c}\mathrm{ns} \\
0.78 \\
0.91 \\
0.77 \\
\mathrm{~ns} \\
\mathrm{~ns} \\
\mathrm{X}\end{array}$ & $\begin{array}{c}\text { ns } \\
\text { ns } \\
\text { ns } \\
\text { ns } \\
\text { ns } \\
\text { ns } \\
\text { ns } \\
\text { X }\end{array}$ & $\begin{array}{c}\mathrm{ns} \\
0.58 \\
0.65 \\
0.67 \\
0.80 \\
0.59 \\
0.61 \\
\mathrm{~ns} \\
\mathrm{X}\end{array}$ & $\begin{array}{c}0.66 \\
\mathrm{~ns} \\
\mathrm{~ns} \\
\mathrm{~ns} \\
\mathrm{~ns} \\
0.56 \\
0.74 \\
\mathrm{~ns} \\
\mathrm{~ns} \\
\mathrm{X}\end{array}$ \\
\hline Bottom & $\begin{array}{l}\text { FL bacteria } \\
\text { PA bacteria } \\
\text { Total bacteria } \\
\text { SPM } \\
\text { Chl a } \\
\text { Phaeo } \\
\text { Phaeo (\% chl) } \\
\text { DFAA } \\
\text { DFAA-Tr } \\
\text { BP }\end{array}$ & $\begin{array}{l}\mathrm{ns} \\
\mathrm{X}\end{array}$ & $\begin{array}{c}\text { ns } \\
0.90 \\
\text { X }\end{array}$ & $\begin{array}{c}\mathrm{ns} \\
0.84 \\
0.82 \\
\mathrm{X}\end{array}$ & $\begin{array}{c}\mathrm{ns} \\
0.61 \\
\mathrm{~ns} \\
0.66 \\
\mathrm{X}\end{array}$ & $\begin{array}{c}\mathrm{ns} \\
0.58 \\
0.69 \\
\mathrm{~ns} \\
\mathrm{~ns} \\
\mathrm{X}\end{array}$ & $\begin{array}{c}\text { ns } \\
0.56 \\
0.64 \\
\text { ns } \\
\text { ns } \\
\text { ns } \\
\text { X }\end{array}$ & $\begin{array}{c}\mathrm{ns} \\
\mathrm{ns} \\
\mathrm{ns} \\
\mathrm{ns} \\
0.60 \\
\mathrm{~ns} \\
\mathrm{~ns} \\
\mathrm{X}\end{array}$ & $\begin{array}{c}\text { ns } \\
0.80 \\
0.76 \\
\text { ns } \\
0.69 \\
\text { ns } \\
0.66 \\
\text { ns } \\
\text { X }\end{array}$ & $\begin{array}{c}\mathrm{ns} \\
\mathrm{ns} \\
\mathrm{ns} \\
\mathrm{ns} \\
\mathrm{ns} \\
\mathrm{ns} \\
0.66 \\
\mathrm{~ns} \\
\mathrm{~ns} \\
\mathrm{X}\end{array}$ \\
\hline
\end{tabular}

resuspended particulates from the bottom to the surface. Therefore, it is not surprising that these asymmetrical tidal patterns of most SPM-associated and microbial parameters did not correlate with current velocity. Similar observations have been reported by Poremba et al. (1999) and Lunau et al. (2006).

Interestingly, the tidal patterns of BP were different from those of the SPM-associated parameters, because BP includes the activity of both FL and PA bacteria, which exhibited different tidal patterns. Unfortunately, we were unable to determine BP (and neither DFAA turnover rate constants) of PA bacteria because of a very high background of radioactivity on the $5 \mu \mathrm{m}$ filters used for collecting the PA bacteria in the SPM-rich samples. PA bacteria constituted 30 to $40 \%$ of total bacterial numbers (Table 3 ) but presumably a higher percentage of BP because of the usually higher activity per cell of PA bacteria relative to FL bacteria (e.g. Grossart et al. 2007). Therefore, we assume that PA bacteria contributed higher proportions to BP around mean tide and FL bacteria higher proportions around low tide, thus yielding the enhanced rates of $\mathrm{BP}$ observed from outgoing to incoming mean tides.

In contrast to BP, DFAA turnover rate constants exhibited maxima at mean tide, indicating that amino acid turnover was related to current velocity and tidal patterns of POM and PA bacteria. It has been shown that PA bacteria exhibit enhanced rates of ectoproteolytic activities and release dissolved amino acids by solubilizing particulate combined amino acids (PCAA, Smith et al. 1992, Simon et al. 2002). We assume that higher current velocities around mean tide lead to resuspension and thus enhanced values of POM and PA bacteria in the water column. They also enhance the turnover of DFAA by PA bacteria, presumably due to bacterial proteolysis of PCAA (Smith et al. 1992). In fact, absolute DFAA turnover rate constants were very high, often $>0.1 \mathrm{~h}^{-1}$ and up to $0.38 \mathrm{~h}^{-1}$ (Table 3), equivalent to turnover times of $\sim 3$ to $10 \mathrm{~h}$.

The high DFAA concentrations, i.e. > $300 \mathrm{nM}$, sometimes almost similar to concentrations of dissolved 
combined amino acids, also indicate high solubilization rates of polymeric, i.e. particulate and dissolved amino acids, and thus high release rates of DFAA. Physico-chemical desorption and release from resuspended sediments presumably was another source of DFAA and dissolved combined amino acids. It has been shown experimentally that dissolved amino acids are rapidly released from resuspended estuarine sediments (Tappin et al. 2007). DFAA concentrations in the same range found in the present study have also been reported in other studies in the Wadden Sea and estuarine systems with high loads of SPM and high bacterial activities (Coffin 1989, Grossart et al. 2004, Lunau et al. 2006). The high DFAA concentrations may indicate an uncoupled desorption and release of sediment-associated amino acids and hydrolysis of polymeric amino acids from bacterial uptake of DFAA because of saturated uptake systems. In fact, DFAA incorporation rates, calculated on the basis of turnover rate constants and DFAA concentrations, greatly exceeded BP rates in January, April and November (Table 3). Only in July at DFAA concentrations of $<0.3 \mu \mathrm{M}$ and tidal means of $<0.11 \mu \mathrm{M}$ were DFAA incorporation rates always below BP rates. Assuming that uptake systems of the most abundant single amino acids (glutamate, glycine, serine and alanine; together constituting about $80 \mathrm{~mol} \%$ of DFAA) were saturated at concentrations of only 10 to $15 \%$ of the high concentrations found in January and April, and at 30 to $50 \%$ of the values in November, DFAA incorporation rates would decline to values equivalent to BP rates. Despite these ambiguities with DFAA incorporation rates, the rapid DFAA turnover rate constants and the high DFAA concentrations indicate that amino acids were turned over rapidly and are an important substrate for growth of heterotrophic bacteria in the Wadden Sea.

In addition to the intense amino acid turnover fuelling growth of heterotrophic bacteria, the high bacterial metabolic activity and decomposition of organic matter during the growing season in April and July was also evident from the short bulk generation time of 1 to $2 \mathrm{~d}$. Despite these short bulk generation times and the pronounced variations of PA bacterial numbers during the tidal cycles, the composition of the community of PA and FL bacteria remained very stable during the tidal cycles (Rink et al. 2008). This suggests that general growth and substrate conditions remained unchanged during a tidal cycle and/or were not reflected on the level of the bacterial community composition assessed. Changes in the bacterial community composition did occur, but on longer time scales than days, in response to the development of phytoplankton blooms and their changing supply of dissolved organic matter to heterotrophic bacteria (Rink et al. 2007).
The rates of BP of 0.5 to $>2 \mu \mathrm{g} \mathrm{C} \mathrm{l}^{-1} \mathrm{~h}^{-1}$ we found are very high, translating into 211 and $785 \mathrm{mg} \mathrm{C} \mathrm{m}^{-2}$ $\mathrm{d}^{-1}$ in April and July, respectively, and explain the short generation times. These BP rates are, however, in the same range as values reported from the North Frisian Wadden Sea (Poremba et al. 1999) and higher than those from the southern North Sea (Reinthaler \& Herndl 2005) and oceanic systems (Kirchman et al. 2009). They emphasize the high productivity of intertidal flat systems which have been reported to be heterotrophic (Cadée 1980, Postma 1981). In order to examine whether this is also true for the Spiekeroog intertidal flat system, comparative primary production data are needed. Unfortunately, primary production data are not available for the East Frisian Wadden Sea. However, these values are likely in the same range as primary production in the North Frisian Wadden Sea ( 200 to $1000 \mathrm{mg} \mathrm{C} \mathrm{m}^{-2} \mathrm{~d}^{-1}$; Poremba et al. 1999), an intertidal flat system with BP values similar to those found in the present study. To estimate total bacterial consumption of organic matter in addition to rates of $\mathrm{BP}$, the bacterial growth efficiency (BGE) needs to be considered. We did not determine BGE but assume values of 15 and $30 \%$, which are the lower and upper limit for the southern North Sea from April to October (Reinthaler \& Herndl 2005). Hence, daily rates of BP translate into rates of total bacterial consumption of organic matter of between 703 and $1403 \mathrm{mg} \mathrm{C} \mathrm{m}^{-2} \mathrm{~d}^{-1}$ in April and between 2616 and $5232 \mathrm{mg} \mathrm{C} \mathrm{m}^{-2} \mathrm{~d}^{-1}$ in July, respectively. These values are much higher than the daily primary production rates mentioned above and are considered representative of the East Frisian Wadden Sea. Also, the fact that oxygen was supersaturated only during the daytime of the tidal cycle in April but remained undersaturated during the night and the other tidal cycles clearly indicates that bacterial consumption of organic matter exceeded primary production. These notions strongly suggest that the East Frisian Wadden Sea is also a net-heterotrophic system, which is consistent with early reports of intertidal flat systems acting as a sink for organic matter (Cadée 1980, Postma 1981) and as a source of $\mathrm{CO}_{2}$ for the atmosphere (Thomas et al. 2007).

\section{CONCLUSIONS}

Our study has shown that the abundance of FL and PA bacteria, DFAA turnover and BP exhibit pronounced tidal variations, seasonally and vertically, with an increasing significance of PA bacteria towards the bottom in the growing season. These variations are modulations of general tidal patterns of these parameters, which become evident from normalized tidal pat- 
terns. Our results complement previous findings of regular tidal patterns of SPM-associated properties. The data on oxygen saturation, bacterioplankton growth, BP and DFAA turnover further showed that bacterial growth and consumption of organic matter in the Spiekeroog intertidal flat system are very intense and suggest that this system is net-heterotrophic. The tidally varying microbial activities with maxima around mean tide indicate that the rhythmic tidal currents support these activities and favour the decomposition of organic matter by heterotrophic bacteria in the water column of intertidal flat systems.

Acknowledgements. We thank B. Kuerzel, A. Schlingloff, R. Weinert and the captain and crew of RV 'Senckenberg' for technical assistance in the field and in the lab and for excellent cooperation. The constructive comments and suggestions of 3 reviewers on an earlier version of this publication are gratefully acknowledged. This work was supported by Deutsche Forschungsgemeinschaft within the Research Unit BioGeoChemistry of Tidal Flats (FG 432-TP5, TPB).

\section{LITERATURE CITED}

Admiraal W, Beukema J, van Es FB (1985) Seasonal fluctuation in the biomass and metabolic activity of bacterioplankton and phytoplankton in a well-mixed estuary: the Ems-Dollard (Wadden Sea). J Plankton Res 7:877-890

Alongi DM (1998) Coastal ecosystem processes. CRC Press, Boca Raton, FL

Bartholomä A, Kubicki A, Badewien T, Flemming BW (2009) Suspended sediment transport in the German Wadden Sea - seasonal variations and extreme events. Ocean Dyn 59:213-225

Berman T, Bronk DA (2003) Dissolved organic nitrogen: a dynamic participant in aquatic ecosystems. Aquat Microb Ecol 31:279-305

> Cadée GC (1980) Reappraisal of the production and import of organic matter in the western Wadden Sea. Neth J Sea Res 14:305-322

Chen S, Eisma D, Kalf J (1994) In situ size distribution of suspended matter during the tidal cycle in the Elbe estuary. Neth J Sea Res 32:37-48

Coffin RB (1989) Bacterial uptake of dissolved free and combined amino acids in estuarine waters. Limnol Oceanogr 34:531-542

Dellwig O, Beck M, Lemke A, Lunau M, Kolditz K, Schnetger B, Brumsack HJ (2007) Non-conservative behaviour of molybdenum in coastal waters: coupling geochemical, biological, and sedimentological processes. Geochim Cosmochim Acta 71:2745-2761

Eisma D, Li A (1993) Changes in suspended-matter floc size during the tidal cycle in the Dollard Estuary. Neth J Sea Res 31:107-117

Grossart HP, Brinkhoff T, Martens T, Duerselen C, Liebezeit G, Simon M (2004) Tidal dynamics of dissolved and particulate matter and bacteria in a tidal flat ecosystem in spring and fall. Limnol Oceanogr 49:2212-2222

> Grossart HP, Tang KW, Kiørboe T, Ploug H (2007) Comparison of cell-specific activity between free-living and attached bacteria using isolates and natural assemblages. FEMS Microbiol Lett 266:194-200
Kirchman DL, Morán XAG, Ducklow HW (2009) Microbial growth in the polar oceans - role of temperature and potential impact of climate change. Nat Rev Microbiol 7: 451-459

Lee S, Fuhrman JA (1987) Relationship between biovolume and biomass of naturally derived marine bacterioplankton. Appl Environ Microbiol 53:1298-1303

Lemke A, Lunau M, Stone J, Dellwig O, Simon M (2009) Spatio-temporal dynamics of suspended matter properties and bacterial communities in the back-barrier tidal flat system of Spiekeroog Island. Ocean Dyn 59:277-290

> Lucas CH, Holligan PM (1999) Nature and ecological implications of algal pigment diversity on the Molenplaat tidal flat (Westerschelde estuary, SW Netherlands). Mar Ecol Prog Ser 180:51-64

$>$ Lunau M, Lemke A, Walther K, Martens-Habbena W, Simon M (2005) An improved method for counting bacteria in samples with high proportions of particle-associated cells by epifluorescence microscopy. Environ Microbiol 7:961-968

> Lunau M, Lemke A, Dellwig O, Simon M (2006) Physical and biogeochemical controls of microaggregate dynamics in a tidally affected coastal ecosystem. Limnol Oceanogr 51: 847-859

Nusch EA (1999) Chlorophyllbestimmung. In: von Tümpling W, Friedrich G (eds) Biologische Gewässeruntersuchung. Gustav Fischer Verlag, Jena, p 368-375

> Poremba K, Tillmann U, Hesse KJ (1999) Tidal impact on planktonic primary and bacterial production in the German Wadden Sea. Helgol Mar Res 53:19-27

Postma H (1981) Exchange of materials between the North Sea and the Wadden Sea. Mar Geol 40:199-213

> Reinthaler T, Herndl GJ (2005) Seasonal dynamics of bacterial growth efficiency in relation to phytoplankton in the southern North Sea. Aquat Microb Ecol 39:7-16

Reuter R, Badewien TH, Bartholomä A, Braun A, Lübben A, Rullkötter J (2009) A hydrographic time-series station in the Wadden Sea (southern North Sea). Ocean Dyn 59: 195-211

> Rink B, Seeberger S, Martens T, Duerselen C, Simon M, Brinkhoff T (2007) Effects of a phytoplankton bloom in a coastal ecosystem on the composition of bacterial communities. Aquat Microb Ecol 48:47-60

Rink B, Martens T, Fischer D, Lemke A, Grossart HP, Simon M, Brinkhoff T (2008) Short-term dynamics of bacterial communities in a tidally affected coastal ecosystem. FEMS Microbiol Ecol 66:306-319

Rullkötter J (2009) The back-barrier tidal flats in the southern North Sea - a multidisciplinary approach to reveal the main driving forces shaping the system. Ocean Dyn 59: 157-165

Simon M (1998) Bacterioplankton dynamics in a large mesotrophic lake: II. Concentrations and turnover of dissolved amino acids. Arch Hydrobiol 144:1-23

Simon M, Azam F (1989) Protein content and protein synthesis rates of planktonic marine bacteria. Mar Ecol Prog Ser 51:201-213

Simon M, Grossart HP, Schweitzer B, Ploug H (2002) Microbial ecology of organic aggregates in aquatic ecosystems. Aquat Microb Ecol 28:175-211

Smith DC, Simon M, Alldredge AL, Azam F (1992) Intense hydrolytic enzyme activity on marine aggregates and implications for rapid particle dissolution. Nature 359: $139-142$

> Soetaert K, Herman PMJ (1995) Carbon flows in the Westerschelde estuary (The Netherlands) evaluated by means of an ecosystem model (MOSES). Hydrobiologia 311: $247-266$ 
Stanev E, Grayek S, Staneva J (2009) Temporal and spatial circulation patterns in the East Frisian Wadden Sea. Ocean Dyn 59:167-181

Tappin AD, Millward GE, Fitzsimons MF (2007) Distributions, cycling and recovery of amino acids in estuarine waters and sediments. Environ Chem Lett 5:161-167

Thomas $\mathrm{H}$, Prowe AEF, van Heuven S, Bozec Y and others (2007) Rapid decline of the $\mathrm{CO}_{2}$ buffering capacity in the North Sea and implications for the North Atlantic Ocean. Global Biogeochem Cycles 21:GB4001 doi:10.1029/2006 GB002825

Tillmann U, Hesse KJ, Colijn F (2000) Planktonic primary production in the German Wadden Sea. J Plankton Res 22:1253-1276

Underwood GJC, Kromkamp J (1999) Primary production by

Editorial responsibility: Ruben Sommaruga,

Innsbruck, Austria phytoplankton and microphytobenthos in estuaries. Adv Ecol Res 29:93-153

Van Duyl FC, Kop AJ (1988) Temporal and lateral fluctuations in production and biomass of bacterioplankton in the western Dutch Wadden Sea. Netherlands J Sea Res 22: 51-68

Van Leussen W (1996) Erosion/sedimentation cycles in the Ems estuary. Arch Hydrobiol Spec Issues Advanc Limnol 47:179-193

Wolfstein K, Colijn F, Doerffer R (2000) Seasonal dynamics of microphytobenthos biomass and photosynthetic characteristics in the northern German Wadden Sea, obtained by the photosynthetic light dispension system. Estuar Coast Shelf Sci 51:651-662

Submitted: March 11, 2010; Accepted: August 12, 2010 Proofs received from author(s): October 22, 2010 